\title{
Reclassification of Agrobacterium ferrugineum LMG 128 as Hoeflea marina gen. nov., sp. nov.
}

Correspondence

Encarna Velázquez evp@gugu.usal.es

\author{
Alvaro Peix, ${ }^{1}$ Raúl Rivas, ${ }^{2}$ Martha E. Trujillo, ${ }^{2}$ Marc Vancanneyt, ${ }^{3}$ \\ Encarna Velázquez ${ }^{2}$ and Anne Willems ${ }^{3}$
}

\author{
${ }^{1}$ Departamento de Producción Vegetal, Instituto de Recursos Naturales y Agrobiología, \\ IRNA-CSIC, Spain \\ 2Departamento de Microbiología y Genética, Lab. 209, Edificio Departamental, Campus Miguel \\ de Unamuno, Universidad de Salamanca, 37007 Salamanca, Spain \\ ${ }^{3}$ Laboratory of Microbiology, Dept Biochemistry, Physiology and Microbiology, Faculty of
Sciences, Ghent University, Ghent, Belgium
}

\begin{abstract}
Members of the species Agrobacterium ferrugineum were isolated from marine environments. The type strain of this species (=LMG $22047^{\top}=$ ATCC $25652^{\top}$ ) was recently reclassified in the new genus Pseudorhodobacter, in the order 'Rhodobacterales' of the class 'Alphaproteobacteria'. Strain LMG 128 (=ATCC 25654) was also initially classified as belonging to the species Agrobacterium ferrugineum; however, the nearly complete 16S rRNA gene sequence of this strain indicated that it does not belong within the genus Agrobacterium or within the genus Pseudorhodobacter. The closest related organism, with 95.5\% 16S rRNA gene similarity, was Aquamicrobium defluvii from the family 'Phyllobacteriaceae' in the order 'Rhizobiales'. The remaining genera from this order had 16S rRNA gene sequence similarities that were lower than $95 \cdot 1 \%$ with respect to strain LMG 128 . These phylogenetic distances suggested that strain LMG 128 belonged to a different genus. The major fatty acid present in strain LMG 128 was mono-unsaturated straight chain $18: 1 \omega 7 \mathrm{c}$. The $\mathrm{G}+\mathrm{C}$ content of the DNA was $53.1 \mathrm{~mol} \%$. Strain LMG 128 grew at $4{ }^{\circ} \mathrm{C}$ but not at $40{ }^{\circ} \mathrm{C}$, and tolerated up to $5 \% \mathrm{NaCl}$. The pH range for growth was 6-8. It produced urease and $\beta$-galactosidase, and hydrolysed aesculin. Denitrification was negative. Growth was observed with many carbohydrates as the only carbon source. The data from this polyphasic study indicate that this strain belongs to a new genus of the family 'Phyllobacteriaceae', and therefore it is proposed that strain LMG $128^{\top}$ should be reclassified as representing a novel species within the new genus Hoeflea gen. nov., for which the name Hoeflea marina sp. nov. is proposed.
\end{abstract}

The species Agrobacterium ferrugineum was originally described by Ahrens and co-workers (Ahrens, 1968; Ahrens \& Rheinheimer, 1967) for star-shaped Agrobacterium-like organisms. In the 8th edition of Bergey's Manual of Determinative Bacteriology, Ahrens withdrew her proposal of classifying these organisms as Agrobacterium ferrugineum (Allen \& Holding, 1974) and the species was not included in the Approved Lists (Skerman et al., 1980). However, Rüger \& Höfle (1992) revived the name Agrobacterium

Published online ahead of print on 14 January 2005 as DOI 10.1099/ ijs.0.63291-0.

The GenBank/EMBL/DDBJ accession number for the $16 \mathrm{~S}$ rRNA gene sequence of strain LMG $128^{\top}$ is AY598817.

A neighbour-joining tree based on nearly complete $16 \mathrm{~S}$ rRNA gene sequences of Hoeflea marina LMG $128^{\top}$ and related organisms of the family 'Phyllobacteriaceae' is available as supplementary material in IJSEM Online. ferrugineum when they described marine, star-shaped, aggregate-forming bacteria. The type strain (=Ahrens $\mathrm{A} 7^{\mathrm{T}}=\mathrm{ATCC} 25652^{\mathrm{T}}$ ) of this species has been recently reclassified as belonging to the new genus Pseudorhodobacter (Uchino et al., 2002). Strain LMG 128 (=Ahrens A43= ATCC 25654) was initially included in the species Agrobacterium ferrugineum (Ahrens, 1968), but this strain was not studied by Rüger \& Höfle (1992), who only took into consideration the type strain in their study (=Ahrens $\mathrm{A} 7^{\mathrm{T}}=\mathrm{ATCC} 25652^{\mathrm{T}}$ ). The nearly complete sequence of the $16 \mathrm{~S}$ rRNA-encoding gene of LMG 128 indicates that it does not belong to the genus Agrobacterium, or to the genus Pseudorhodobacter, but to a new genus within the family 'Phyllobacteriaceae'. In the present study we describe the phylogenetic, morphological, chemotaxonomic and physiological characteristics of this organism. On the basis of these data, we propose to place strain LMG $128^{\mathrm{T}}$ within a new genus, Hoeflea, as Hoeflea marina gen. nov., sp. nov. 
DNA extraction, PCR of the $16 \mathrm{~S}$ rRNA gene and sequencing of the PCR products were performed as previously described (Rivas et al., 2002). A nearly complete 16 S rRNA gene sequence (1477 nucleotides) was obtained and was compared with those deposited in the databases. Sequences were aligned using the CLUSTAL_X software (Thompson et al., 1997). Distances were calculated according to Kimura's two-parameter method (Kimura, 1980). Phylogenetic trees were inferred by using the neighbour-joining method (Saitou \& Nei, 1987). The bootstrap analysis was based on 1000 resamplings. The MEGA 2 package (Kumar et al., 2001) was used for all analyses. Based on the 16S rRNA gene sequence analysis, strain LMG $128^{\mathrm{T}}$ formed a new branch within the family 'Phyllobacteriaceae' (Fig. 1), and its closest relatives were Aquamicrobium defluvii (Bambauer et al., 1998) and Defluvibacter lusatiensis (Fritsche et al., 1999), with 16S rRNA gene sequence similarities of 95.5 and $95 \cdot 1 \%$, respectively (a more complete phylogenetic tree is available as supplementary material in IJSEM Online).

Strain LMG $128^{\mathrm{T}}$ was grown on nutrient agar for $48 \mathrm{~h}$ at $22{ }^{\circ} \mathrm{C}$, to check for motility by phase-contrast microscopy. The cells were also stained according to the classical Gram procedure described by Doetsch (1981). The morphological characteristics of strain LMG $128^{\mathrm{T}}$ are presented in the species description.

For fatty acid methyl ester (FAME) analysis, strain LMG $128^{\mathrm{T}}$ was cultivated for $24 \mathrm{~h}$ at $28^{\circ} \mathrm{C}$ on TSBA plates containing $30 \mathrm{~g}$ trypticase soy broth (BBL), supplemented with $15 \mathrm{~g}$ Bacto agar (1 distilled water) ${ }^{-1}$ (Difco). The cells were saponified, and the fatty acids were methylated to FAMEs and extracted following the Sherlock Microbial Identification System version 3.0 (MIDI, 1999). FAMEs were separated on an Agilent 6890A series gas chromatograph, with 7683 autoinjector and autosampler tray module (Agilent Technologies). Separation of FAMEs was achieved with a fusedsilica capillary column $(25 \mathrm{~m} \times 0 \cdot 2 \mathrm{~mm})$, with cross-linked $5 \%$ phenylmethyl silicone (film thickness, $0.33 \mu \mathrm{m}$; HP Ultra2). Hydrogen served as the carrier gas. Peak integration and identification were performed using the Hewlett Packard Chemstation software and Sherlock software. The results of the analysis are shown in Table 1. For comparison, the type strains of Aquamicrobium defluvii and Pseudorhodobacter ferrugineus were also included. As $P$. ferrugineus could not be grown on TSBA, it was grown on marine agar (Medium 12; BCCM/LMG catalogue of strains, http://

\section{Table 1. FAME profiles}

Strains: 1, H. marina LMG $128^{\mathrm{T}}$; 2, Aquamicrobium defluvii LMG $22048^{\mathrm{T}} ; 3$, P. ferrugineus LMG $22047^{\mathrm{T}}$. Values are mean percentages of total FAMEs. Only fatty acids accounting for more than $1 \cdot 0 \%$ (mean amount) are indicated. tr, Trace amount $(\leqslant 1 \cdot 0 \%)$; ND, not detected.

\begin{tabular}{|lccc|}
\hline FAME & $\mathbf{1}$ & $\mathbf{2}$ & $\mathbf{3}$ \\
\hline $10: 03-\mathrm{OH}$ & $\mathrm{ND}$ & $\mathrm{ND}$ & $4 \cdot 0-6 \cdot 4$ \\
$12: 03-\mathrm{OH}$ & $\mathrm{ND}$ & $2 \cdot 5$ & $\mathrm{ND}$ \\
$16: 0$ & $4 \cdot 0$ & $2 \cdot 4$ & $2 \cdot 6-2 \cdot 7$ \\
$17: 0$ & $\mathrm{ND}$ & $2 \cdot 1$ & $\mathrm{tr}$ \\
$17: 1 \omega 6 c$ & $\mathrm{ND}$ & $1 \cdot 5$ & $\mathrm{ND}$ \\
$17: 1 \omega 8 c$ & $\mathrm{tr}$ & $2 \cdot 6$ & $\mathrm{ND}$ \\
$18: 0$ & $1 \cdot 4$ & $2 \cdot 7$ & $3 \cdot 0-4 \cdot 6$ \\
$18: 1 \omega 7 c$ & $76 \cdot 0$ & $80 \cdot 7$ & $61 \cdot 3-66 \cdot 5$ \\
$18: 1 \omega 9 c$ & $\mathrm{ND}$ & $\mathrm{ND}$ & $1 \cdot 7-2 \cdot 1$ \\
$18: 1 \omega 7 c$ 11Me & $7 \cdot 5$ & $\mathrm{ND}$ & $\mathrm{ND}$ \\
Unknown ECL $18 \cdot 797$ & $\mathrm{ND}$ & $1 \cdot 8$ & $\mathrm{ND}$ \\
$19: 0$ cyclo $\omega 8 c$ & $5 \cdot 6$ & $1 \cdot 2$ & $\mathrm{ND}$ \\
$20: 1 \omega 9 t$ & $\mathrm{tr}$ & $1 \cdot 5$ & $\mathrm{ND}$ \\
Summed feature $4 *$ & $2 \cdot 6$ & $\mathrm{ND}$ & $\operatorname{tr}$ \\
Unknown ECL $11 \cdot 798$ & $\mathrm{ND}$ & $\mathrm{ND}$ & $3 \cdot 2-4 \cdot 7$ \\
Unknown ECL $15 \cdot 275$ & $\mathrm{ND}$ & $\mathrm{ND}$ & $3 \cdot 6-5 \cdot 2$ \\
Unknown ECL $17 \cdot 606$ & $\mathrm{tr}$ & $\mathrm{ND}$ & $11 \cdot 4-13 \cdot 1$ \\
& & & \\
\hline
\end{tabular}

* Summed feature 4 consisted of one or both of the following fatty acids, which could not be separated by the Microbial Identification System: $16: 1 \omega 7 c$ and $15: 0$ iso $2-\mathrm{OH}$.

www.belspo.be/bccm/db/media.htm). All three strains contained as a major component the mono-unsaturated straight-chain $18: 1 \omega 7 c(60-80 \%)$. Minor fatty acids were the saturated straight-chain components $16: 0$ and $18: 0$. No significant hydroxy fatty acids were detected in LMG $128^{\mathrm{T}}$ (summed feature 3, comprising 14:0 $3-\mathrm{OH}$ and 16:1 iso, which could not be separated, was present at less than $1 \%$ ), whereas Aquamicrobium defluvii and P. ferrugineus contained 12:0 3-OH and 10:0 3-OH, respectively. For $D$. lusatiensis, Fritsche et al. (1999) reported that the main component was octadecanoic acid $(18: 1)$ and that $12: 03$ $\mathrm{OH}$ was present as a diagnostic component in small amounts. Strain LMG $128^{\mathrm{T}}$ contained a significant amount $(7 \cdot 5 \%)$ of $18: 1 \omega 7 c 11 \mathrm{Me}$, whereas no methylated fatty

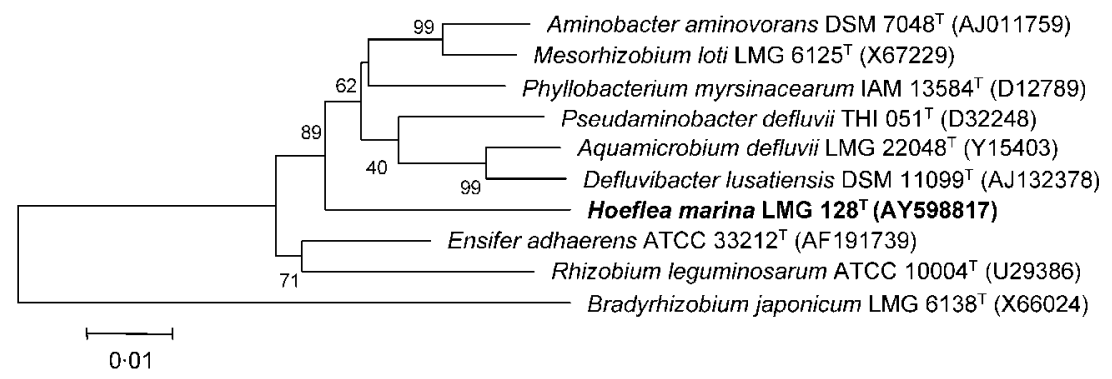

Fig. 1. Neighbour-joining tree based on nearly complete $16 \mathrm{~S}$ rRNA gene sequences of $H$. marina LMG $128^{\top}$ and other related organisms of the family 'Phyllobacteriaceae'. The significance of each branch is indicated by a bootstrap percentage calculated for 1000 subsets. Bar, 1 estimated substitution per 100 base positions. 
acids were detected in the other strains. To exclude the possibility that the original strain LMG $128^{\mathrm{T}}$, deposited by R. Ahrens in 1969, had been contaminated or mislabelled during strain maintenance at the culture collection, we included lyophilized cultures from different batches, from 1973 and 1992. Both had identical FAME patterns.

Quinone and lipid compositions were determined by HPLC (Tindall, 1990a, b). Similar to other related genera from the order 'Rhizobiales' (Fritsche et al., 1999), the major respiratory lipoquinone in strain LMG128 ${ }^{\mathrm{T}}$ was ubiquinone Q-10. The polar lipid pattern of strain LMG $128^{\mathrm{T}}$ was composed of phosphatidylglycerol, phosphatidylethanolamine, phosphatidylmonomethylethanolamine and sulphoquinovosyldiacylglyceride. Small amounts of diphosphatidylglycerol, an unidentified phospholipid and an unidentified phosphoglycolipid were also detected.

DNA from strain LMG $128^{\mathrm{T}}$ was prepared according to Chun \& Goodfellow (1995). The mol\% G+C content was determined by using the thermal denaturation method (Mandel \& Marmur, 1968). The $\mathrm{G}+\mathrm{C}$ content of strain LMG $128^{\mathrm{T}}$ was $53 \cdot 1 \mathrm{~mol} \%$.

Catalase and oxidase activities were determined as described previously (Rivas et al., 2003). Other physiological and biochemical tests were done by using API 20NE (bioMérieux), according to the manufacturer's instructions. $P$. ferrugineus LMG $22047^{\mathrm{T}}$ and Aquamicrobium defluvii LMG $22048^{\mathrm{T}}$ were also included for comparison. The temperature range for growth was determined by incubating cultures on Yeast Mannitol agar (YMA) medium (Vincent, 1970) at $4-45^{\circ} \mathrm{C}$. The $\mathrm{pH}$ range was determined on YMA medium, with a final $\mathrm{pH}$ between $4 \cdot 0$ and $9 \cdot 0$. Salt tolerance was studied on YMA medium containing 0-8\% (w/v) $\mathrm{NaCl}$. Differentiating physiological characteristics are listed in Table 2 . They clearly demonstrate that strain LMG $128^{\mathrm{T}}$ is different from strains of neighbouring genera.

In conclusion, the results of the present study, including a low similarity value for the $16 \mathrm{~S}$ rRNA gene sequence and differences in the chemotaxonomical, morphological and physiological analyses, indicate that isolate $\mathrm{LMG} 128^{\mathrm{T}}$ is not related to $P$. ferrugineus and should be reclassified as representing a novel species within a new genus, for which we propose the name Hoeflea gen. nov., with Hoeflea marina sp. nov. as the type species.

\section{Description of Hoeflea gen. nov.}

Hoeflea (Hoef.le.a'. N.L. fem. n. Hoeflea honouring Manfred Höfle, German microbiologist, in recognition of his contribution to the taxonomy of marine bacteria).

Gram-negative, non-spore-forming, short, regular and motile rod-shaped cells. Strictly aerobic and chemoorganotrophic. Oxidase- and catalase-positive. Grow in the presence of $\mathrm{NaCl}$ concentrations up to $5 \%(\mathrm{w} / \mathrm{v})$, although salt is not essential for growth. Temperature range for growth is $4-37^{\circ} \mathrm{C}$ and the $\mathrm{pH}$ range for growth is $6-8$.
Table 2. Differentiating characteristics among the strains from this study

Strains: 1, H. marina LMG $128^{\mathrm{T}}$; P. ferrugineus LMG $22047^{\mathrm{T}}$; 3 , Aquamicrobium defluvii LMG $22048^{\mathrm{T}} ; 4$, D. lusatiensis DSM $11099^{\mathrm{T}}$ (data from Fritsche et al., 1999). +, Positive; -, negative; W, weak; ND, no data.

\begin{tabular}{|c|c|c|c|c|}
\hline Characteristic & 1 & 2 & 3 & 4 \\
\hline Cell shape & Short rods & Rods & Rods & Short rods \\
\hline Motility & + & - & + & + \\
\hline \multicolumn{5}{|l|}{ Growth at/in: } \\
\hline $4^{\circ} \mathrm{C}$ & + & ND & - & - \\
\hline $40^{\circ} \mathrm{C}$ & - & ND & + & + \\
\hline pH 9 & - & ND & + & + \\
\hline $5 \% \mathrm{NaCl}$ & + & - & - & ND \\
\hline Denitrification & - & - & + & - \\
\hline Urease & + & $-*$ & $-*$ & - \\
\hline Aesculin hydrolysis & + & $+^{*}$ & $-*$ & - \\
\hline$\beta$-Galactosidase & + & $+^{*}$ & $-{ }^{\star}$ & $\mathrm{ND}$ \\
\hline \multicolumn{5}{|l|}{ Assimilation of: } \\
\hline Mannose & + & $-*$ & + & + \\
\hline Mannitol & + & $-*$ & + & - \\
\hline $\mathrm{N}$-Acetylglucosamine & - & $-*$ & $+^{*}$ & + \\
\hline Gentiobiose & - & $\mathrm{W}^{*}$ & $+^{\star}$ & - \\
\hline Citrate & - & $\mathrm{W}^{\star}$ & $+^{*}$ & - \\
\hline
\end{tabular}

${ }^{\star}$ Data from this study using the API 20NE system.

Do not reduce nitrate to nitrite or nitrogen. The major respiratory lipoquinone is ubiquinone Q-10. The polar lipids are phosphatidylglycerol, phosphatidylethanolamine, phosphatidylmonomethylethanolamine and sulphoquinovosyldiacylglyceride. Diphosphatidylglycerol, an unidentified phospholipid and an unidentified phosphoglycolipid are present in small amounts. The main fatty acid is the unsaturated straight-chain fatty acid $18: 1 \omega 7 c$. Other significant fatty acids $(>3 \%)$ include $16: 0,18: 1 \omega 7 c 11 \mathrm{Me}$ and 19:0 cyclo $\omega 8 c$. Hydroxy fatty acids are present in small amounts. Phylogenetically a member of the family 'Phyllobacteriaceae'. The DNA G $+\mathrm{C}$ content of the type species is $53 \cdot 1 \mathrm{~mol} \%$.

The type species of the genus is Hoeflea marina.

\section{Description of Hoeflea marina sp. nov.}

Hoeflea marina (ma.ri'na. L. fem. adj. marina of the sea, marine, referring to the isolation source of this microorganism, sea water).

In addition to the properties listed in the genus description, the following properties are reported. Colonies on nutrient agar are circular, convex, white-cream, opaque and usually $1-3 \mathrm{~mm}$ in diameter, within 7 days at $28^{\circ} \mathrm{C}$. Cells are short rods of $0 \cdot 7-0 \cdot 9 \times 1 \cdot 1-1 \cdot 4 \mu \mathrm{m}$. Optimal growth occurs at $3 \% \mathrm{NaCl}$. Optimal growth temperature and $\mathrm{pH}$ are $28^{\circ} \mathrm{C}$ and 7 , respectively. Does not produce arginine 
dihydrolase, and hydrolysis of gelatin is weak and slow. Utilizes glucose, L-arabinose, mannose, mannitol, maltose and malate, but not $\mathrm{N}$-acetylglucosamine, gentiobiose, caproate, adipate, citrate or phenylacetate. Fatty acids are listed in Table 1.

The type strain, and so far the only strain, is LMG $128^{\mathrm{T}}$ $\left(=\right.$ ATCC $25654^{\mathrm{T}}$ ), which was isolated from the Baltic Sea, off the coast of Germany. The DNA $\mathrm{G}+\mathrm{C}$ content is $53 \cdot 1 \mathrm{~mol} \%$.

\section{Acknowledgements}

This work was supported by 'Ministerio de Ciencia y Tecnología' and 'Junta de Castilla y León' (Spanish Government). A. W. is grateful to the Fund for Scientific Research-Flanders for a postdoctoral fellowship. We are grateful to Katrien Engelbeen for excellent technical assistance.

\section{References}

Ahrens, R. (1968). Taxonomische Untersuchungen an sternbildenden Agrobacterium-Arten aus der westlichen Ostsee. Kiel Meeresforsch 24, 147-173 (in German).

Ahrens, R. \& Rheinheimer, G. (1967). Über einige sternbildende Bakterien aus der Ostsee. Kiel Meeresforsch 23, 127-136 (in German).

Allen, O. N. \& Holding, A. J. (1974). Genus II. Agrobacterium Conn 1942, 359. Nom. gen. cons. Opn. 33, Jud. Comm. 1970, 10. In Bergey's Manual of Determinative Bacteriology, 8th edn, pp. 264-267. Edited by R. E. Buchanan \& N. E. Gibbons. Baltimore: Williams \& Wilkins.

Bambauer, A., Rainey, F. A., Stackebrandt, E. \& Winter, J. (1998). Characterization of Aquamicrobium defluvii gen. nov., sp. nov., a thiophene-2-carboxylate-metabolizing bacterium from activated sludge. Arch Microbiol 169, 293-302.

Chun, J. \& Goodfellow, M. (1995). A phylogenetic analysis of the genus Nocardia with $16 \mathrm{~S}$ rRNA gene sequences. Int J Syst Bacteriol 45, 240-245.

Doetsch, R. N. (1981). Determinative methods of light microscopy. In Manual of Methods for General Bacteriology, pp. 21-33. Edited by P. Gerdhardt, R. G. E. Murray, R. N. Costilow, E. W. Nester, W. A. Wood, N. R. Krieg \& G. B. Phillips. Washington, DC: American Society for Microbiology.

Fritsche, K., Auling, G., Andreesen, J. R. \& Lechner, U. (1999). Defluvibacter lusatiae gen. nov., sp. nov., a new chlorophenoldegrading member of the $\alpha-2$ subgroup of Proteobacteria. Syst Appl Microbiol 22, 197-204.
Kimura, M. (1980). A simple method for estimating evolutionary rates of base substitutions through comparative studies of nucleotide sequences. J Mol Evol 16, 111-120.

Kumar, S., Tamura, K., Jakobsen, I. B. \& Nei, M. (2001). Molecular Evolutionary Genetics Analysis software. Arizona State University, Tempe, AZ, USA.

Mandel, M. \& Marmur, J. (1968). Use of ultraviolet absorbance temperature profile for determining the guanine plus cytosine content of DNA. Methods Enzymol 12B, 195-206.

MIDI Inc. (1999). Sherlock Microbial Identification System Operating Manual, version 3. Newark, DE: MIDI.

Rivas, R., Velázquez, E., Willems, A., Vizcaíno, N., Subba-Rao, N. S., Mateos, P. F., Gillis, M., Dazzo, F. B. \& Martínez-Molina, E. (2002). A new species of Devosia that forms a nitrogen-fixing root-nodule symbiosis with the aquatic legume Neptunia natans (L. f.) Druce. Appl Environ Microbiol 68, 5217-5222.

Rivas, R., Willems, A., Subba-Rao, N. S., Mateos, P. F., Dazzo, F. B., Martínez-Molina, E., Gillis, M. \& Velázquez, E. (2003). Description of Devosia neptuniae sp. nov. that nodulates and fixes nitrogen in symbiosis with Neptunia natans, an aquatic legume from India. Syst Appl Microbiol 26, 47-53.

Rüger, H.-J. \& Höfle, M. G. (1992). Marine star-shaped-aggregateforming bacteria: Agrobacterium atlanticum sp. nov.; Agrobacterium meteori sp. nov.; Agrobacterium ferrugineum sp. nov., nom. rev.; Agrobacterium gelatinovorum sp. nov., nom. rev.; and Agrobacterium stellulatum sp. nov., nom. rev. Int J Syst Bacteriol 42, 133-143.

Saitou, N. \& Nei, M. (1987). The neighbor-joining method: a new method for reconstructing phylogenetic trees. Mol Biol Evol 4, 406-425.

Skerman, V. B. D., McGowan, V. \& Sneath, P. H. A. (1980). Approved lists of bacterial names. Int J Syst Bacteriol 30, 225-420.

Thompson, J. D., Gibson, T. J., Plewniak, F., Jeanmougin, F. \& Higgins, D. G. (1997). The CLUSTAL_X windows interface: flexible strategies for multiple sequence alignment aided by quality analysis tools. Nucleic Acids Res 25, 4876-4882.

Tindall, B. J. (1990a). A comparative study of the lipid composition of Halobacterium saccharovorum from various sources. Syst Appl Microbiol 13, 128-130.

Tindall, B. J. (1990b). Lipid composition of Halobacterium lacusprofundi. FEMS Microbiol Lett 66, 199-202.

Uchino, Y., Hamada, T. \& Yokota, A. (2002). Proposal of Pseudorhodobacter ferrugineus gen nov, comb nov, for a nonphotosynthetic marine bacterium, Agrobacterium ferrugineum, related to the genus Rhodobacter. J Gen Appl Microbiol 48, 309-319. Vincent, J. M. (1970). The cultivation, isolation and maintenance of rhizobia. In A Manual for the Practical Study of Root Nodule Bacteria, pp. 1-13. Edited by J. M. Vincent. Oxford: Blackwell Scientific. 